\title{
Distribution and host range of an aphidophagous species of Cecidomyiidae, Aphidoletes aphidimyza (Diptera), in Japan
}

\author{
Junichi Yukawa, Daisuke Yamaguchi, ${ }^{1}$ Kuniyuki Mizota ${ }^{2}$ and Osamu Setokuchi ${ }^{3}$ \\ Entomological Laboratory, Faculty of Agriculture, Kyushu University, Fukuoka 812-8581, Japan \\ ${ }^{1}$ Chikushino, Fukuoka 818-0062, Japan \\ ${ }^{2}$ Yame, Fukuoka 834-0052, Japan \\ ${ }^{3}$ Kagoshima Agricultural Experiment Station, Kagoshima 891-0116, Japan
}

(Received 2 September 1997; Accepted 31 October 1997)

\begin{abstract}
Aphidoletes aphidimyza, an aphidophagous species of Cecidomyiidae, has been used in many countries as a biological control agent against aphids, particularly in glasshouses. The species had been reported previously in Japan but a mass-rearing method has not yet been established. Recently, preliminary tests started in Japan to evaluate its effect on aphids using mass-produced cocoons imported from the Netherlands and United Kingdom. Therefore, the natural distribution and host range of $A$. aphidimyza in Japan was studied before Japanese populations are contaminated by mating with imported individuals. Field surveys in 25 prefectures revealed that $A$. aphidimyza is distributed commonly in Japan, except in Okinawa, the most southern prefecture. Nineteen aphid species were observed to be attacked by the Japanese populations of A. aphidimyza and the larvae of imported $A$. aphidimyza were reared to adults on 7 aphid species. As a result, at least 80 host aphid species have now been recorded in the world. Most of the host aphids found in Japan belonged to the tribes Aphidini or Macrosiphini of the subfamily Aphidinae. The host plants of these aphids were also recorded.
\end{abstract}

Key words: Aphidoletes aphidimyza, distribution, host range, aphidophagous Cecidomyiidae, biological control

\section{INTRODUCTION}

Aphidoletes aphidimyza (Rondani) is widely distributed in the world, being recorded from Canada, Chile, China, Egypt, Hawaii, India, Israel, Japan, Russia, Sudan, Tunisia, Turkey, U.S.A., and many European countries (Gagné, 1971; Harris, 1973; Meadow et al., 1985; Kulp et al., 1989; Grover et al., 1988; Zhao and Cheng, 1990; Halima-Kamel and Hamouda, 1993). Larvae of this species feed upon a wide variety of aphids, at least 61 species having been known as hosts (Nijveldt, 1969; Harris, 1973). Most of the aphid species belong to the subfamily Aphidinae, some to Chaitoporinae and Callaphidinae, and a few to other subfamilies. In many countries, $A$. aphidimyza has been used extensively as a biological control agent against aphids, particularly in glasshouses, and has been proved effective (Meadow et al., 1985; Morse and Croft, 1987; Nijveldt, 1988).

The potential for use of $A$. aphidimyza has at- tracted increasing attention in Japan during recent years but a method for mass-rearing has not yet been established. Recently, preliminary tests have been started in some Agricultural Experiment Stations, using mass-produced cocoons imported from the Netherlands and United Kingdom to Japan, in order to evaluate the effect of $A$. aphidimyza on aphid populations in glasshouses.

In Japan, the occurrence of an aphidophagous species of Cecidomyiidae was recorded, for the first time, by Ninomiya (1959), who tentatively identified it as a North American species, Aphidoletes meridionalis Felt, which has since been synonymized with $A$. aphidimyza by Gagné (1971). Subsequently, Yukawa (1971) confirmed the presence of $A$. aphidimyza in Kagoshima Prefecture, but other distribution records based on reliable identification were limited to those of Kato $(1974,1976)$ from Yamaguchi Prefecture. Therefore, it is now necessary to survey the natural distribution and 
abundance of $A$. aphidimyza in Japan before Japanese populations are contaminated by imported individuals. In addition, finding suitable and unsuitable species of host aphid as well as host plants is essential in order to develop massrearing methods using Japanese populations and to grow banker plants (Bennison, 1992) and associated aphids in glasshouses. In particular, the use of Japanese populations is an urgent necessity since they do not cause severe genetic contamination and distributional disturbance in Japan.

In this paper we report the natural distribution, abundance, and host range of $A$. aphidimyza in Japan, based chiefly on recent collection data, together with notes on some other observations.

\section{MATERIALS AND METHODS}

In order to search for larvae of aphidophagous Cecidomyiidae, field surveys were performed, from June 1996 to May 1997, in the following 12 prefectures in Japan: Ibaraki, Yamanashi, Osaka, Wakayama, Okayama, Fukuoka, Nagasaki, Kumamoto, Oita, Miyazaki, Kagoshima, and Okinawa (arranged from north to south). In Kagoshima Prefecture more intensive and frequent surveys were performed at the Kagoshima University Campus and its vicinity from October 1994 to December 1996. In addition, Okinawa Prefecture was visited twice, the first visit in July 1996 and the second in November 1996, since no aphidophagous cecidomyiid larvae were found there during the first visit.

During field surveys, aphid colonies were searched for on various crops and wild plants that were suspected to be possible habitats of both aphids and cecidomyiid predators. When larvae of aphidophagous Cecidomyiidae were found in aphid colonies, they were collected, together with aphids and host plants, and some of them were reared in cylindrical glasses $(12 \mathrm{~cm}$ in diameter, $18 \mathrm{~cm}$ in height) under laboratory conditions in order to obtain adult specimens of both aphidophagous Cecidomyiidae and associated parasitoids, if any.

In response to our request, aphid colonies were surveyed in 1996 at various crop fields or in glasshouses in Agricultural, Horticultural, and
Fruit Tree Experiment Stations (hereafter, AES, HES, FES, respectively) of the following 10 prefectures: Hokkaido, Aomori, Akita, Yamagata, Tokyo, Niigata, Nara, Kagawa, Ehime, and Okinawa. Field surveys were also performed in Hokkaido National Agricultural Experiment Station (hereafter, Hokkaido NAES) and Shikoku National Agricultural Experiment Station (hereafter, Shikoku NAES), of which the latter extended the surveys to 2 neighbouring prefectures, Tokushima and Kochi. The collected midge larvae were forwarded to the laboratory of Kagoshima University together with aphids and host leaves for rearing and identification.

Prior to the present study, larvae of $A$. aphidimyza were sent to J. Yukawa, the senior author of the present paper, for identification, in 1973 from the Ooshima Citrus Branch, Yamaguchi AES and in 1994 from Shimane AES. These collecting data are included in the present study.

In addition to assessing Japanese populations of $A$. aphidimyza, the host range of those imported in May 1995 from Koppert B.V., the Netherlands through Tomen Corporation, Japan was studied by feeding the larvae with several aphid species collected from the Kagoshima University campus. Rearing experiments were performed from May to June 1995 under laboratory conditions using Petri-dishes $(4 \mathrm{~cm}$ in diameter, $2 \mathrm{~cm}$ in depth) containing aphid colonies on a host leaf together with a piece of moistened paper.

Some of the collected larvae and reared adults were mounted on slides, for microscopic study, in Canada balsam using ethanol and xylene. Species identification was made by J. Yukawa relying upon the detailed, illustrated descriptions of A. aphidimyza by Roberti (1946) and Harris (1966) in addition to the original description by Rondani (1847). The specimens are kept in the collection of the Entomological Laboratory, Kyushu University, Fukuoka. Aphid species were identified mostly by O. Setokuchi, one of the co-authors of this paper and partly by Prof. M. Sorin (Kôgakkan Univ.). The aphid specimens are kept in the collection of Kagoshima Agricultural Experiment Station. Ants attending aphid colonies that were attacked by larvae 
of $A$. aphidimyza were also collected, if any, from the fields. They were identified by Mr. K. Tsuda (The Association of Kagoshima Environmental Research and Service).

\section{RESULTS}

\section{Identification}

All aphidophagous cecidomyiid larvae collected through the present surveys and adults reared from some of them were identified as $A$. aphidimyza. In addition, there were no clear diagnostic differences to distinguish Japanese from European specimens at the subspecific level. Besides $A$. aphidimyza, no other Palearctic or Nearctic relatives, such as Aphidoletes urticariae (Kieffer), Aphidoletes abietis (Kieffer), and Aphidoletes thompsonii Möhn, were found during the surveys.

\section{Distribution and abundance of $A$. aphidimyza}

$A$. aphidimyza larvae were collected from 21 (84\%) out of 25 prefectures where field surveys were performed (Fig. 1). This is equivalent to $44.7 \%$ of all 47 prefectures in Japan. The 4 prefectures where $A$. aphidimyza larvae were not found were Aomori, Nara, Ehime, and Okinawa.

Table 1. Percentage of sites where the larvae of $A$. aphidimyza were found

\begin{tabular}{lcc}
\hline Prefecture & $\begin{array}{c}\text { No. of sites } \\
\text { surveyed }\end{array}$ & $\begin{array}{c}\text { Sites where } \\
\text { A. aphidimyza } \\
\text { was found (\%) }\end{array}$ \\
\hline Ibaraki & 10 & $8(80.0)$ \\
Yamanashi & 5 & $2(40.0)$ \\
Osaka & 2 & $2(100.0)$ \\
Wakayama & 6 & $3(50.0)$ \\
Okayama & 2 & $1(50.0)$ \\
Fukuoka & 12 & $8(66.7)$ \\
Nagasaki & 10 & $9(90.0)$ \\
Kumamoto & 8 & $4(50.0)$ \\
Oita & 1 & $1(100.0)$ \\
Miyazaki & 3 & $1(33.3)$ \\
Kagoshima & 10 & $6(60.0)$ \\
\hline Subtotal & 69 & $45(65.2)$ \\
\hline Okinawa (July) & 6 & $0(0)$ \\
\hline Total (Nov.) & 11 & $0(0)$ \\
\hline
\end{tabular}

In Aomori Prefecture, no dipterous larvae, except those of the family Chamaemyiidae, were found. However, the occurrence of $A$. aphidimyza was confirmed in its 2 neighbouring prefectures, Hokkaido and Akita (Fig. 1). Similarly, A. aphidimyza was collected from Osaka and Wakayama both of which are neighbouring prefectures to Nara.

In Ehime Prefecture, A. aphidimyza larvae were collected in September 1996 from the colonies of Macrosiphum euphorbiae (Thomas) on Lycopersicon esculentum (Solanaceae) at Kuma Branch of Ehime AES. However, the collection record was excluded from Fig. 1, since mass-produced cocoons imported from the Netherlands were released there in 1995 to evaluate its effects on aphids (Y. Yamasaki, 1996, personal comm.).

A. aphidimyza was not found in Okinawa Prefecture, in spite of the intensive surveys performed twice in different seasons at a total of 17 different sites (Table 1).

Through the field surveys made by ourselves in the 12 prefectures, the larvae of $A$. aphidimyza were collected at $45(65.2 \%)$ out of 69 sites (Table 1). They were found frequently in household vegetable gardens where insecticides have been seldom used.

\section{Aphid species and their host plants}

Nineteen aphid species that were fed upon by Japanese $A$. aphidimyza are listed in Table 2, together with their host plants. All the aphids, except Myzocallis kuricola (Matsumura) which is a member of the subfamily Drepanosiphinae, belong to the tribes Aphidini or Macrosiphini of the subfamily Aphidinae. Sixteen of them, except Aphis gossypii Glover, Hyalopterus pruni (Geoffroy), and Myzus persicae (Sulzer), were not found in the list of 61 species known as hosts of $A$. aphidimyza in Harris (1973). Most of the aphids collected in Japan are pests of crops, since the field surveys were performed chiefly in crop fields and household vegetable gardens. In particular, $A$. gossypii was attacked most frequently on various host plants in many localities (Table 2).

The larvae derived from $A$. aphidimyza imported from the Netherlands to Japan were reared to adults by feeding with 7 Japanese 


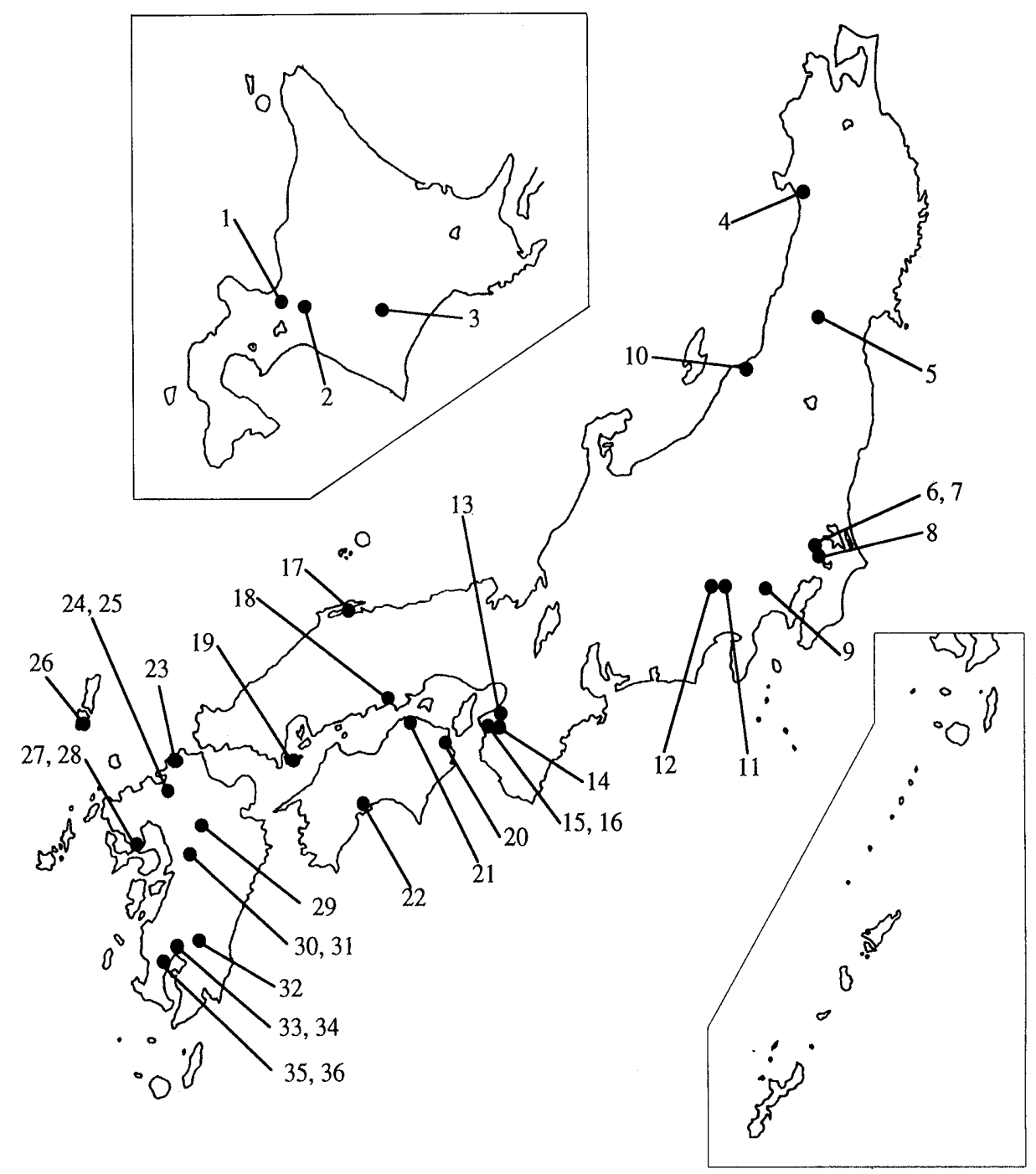

Fig. 1. Collection sites of Aphidoletes aphidimyza in Japan. Numerals indicate collection data as follows: 1, Toyohira, Sapporo City, 2. Aug. 1996; 2, Naganuma, Yubari, Hokkaido, 1. Sep. 1996; 3, Shinsei, Memuro, Hokkaido, 16. Aug. 1996; 4, Niita, Akita City, 30. Aug. 1996; 5, Minorigaoka, Yamagata City, 5. Oct. 1996; 6, Iwama, Nishiibaraki, Ibaraki Pref., 27. Jul. 1996; 7, Hanari, Tsukuba City, 28. Jul. 1996; 8, Inatoi, Toride City, 28. Jul. 1996; 9, Fujimi, Tachikawa City, 7. Aug. 1996; 10, Mano, Seiro, Niigata Pref., 26. Aug. 1996; 11, Tenjin, Kofu City, 1. Aug. 1996; 12, Yoshizawa, Shikishima, Yamanashi Pref., 1. Aug. 1996; 13, Kaminogo, Izumisano City, 3. Aug. 1996; 14, Uchita, Naga, Wakayama Pref., 3. Aug. 1996; 15, Kurusu, Wakayama City, 3. Aug. 1996; 16, Sunayama, Wakayama City, 4. Aug. 1996; 17, Takeya, Matsue City, 27. May 1994; 18, Tamashima, Kurashiki City, 3. Jul. 1996; 19, Agenosho, Tachibana, Yamaguchi Pref., 1. Aug. 1973; 20, Komatsushima City, 10. Sep. 1996; 21, Bussyozan, Takamatsu City, 19. Sep. 1996; 22, Nakaoi, Ino, Kochi Pref., 20. Sep. 1996; 23, Mt. Yukawa, Genkai, Fukuoka Pref., 30. May 1997; 24, Yoshiki, Chikushino City, 18. Jun. 1996; 25, Saifu, Dazaifu City, 18. Jun. 1996; 26, Mt. Tatera, Tsushima, Nagasaki Pref., 30. May 1997; 27, Kaizu, Isahaya City, 20. Jun. 1996; 28, Onihashi, Omura City, 20. Jun. 1996; 29, Kaminoda, Kamitsue, Oita Pref., 19. Jun. 1996; 30, Koshi, Kikuchi City, 6. Jul. 1996; 31, Nishigoshi, Kikuchi City, 6. Jul. 1996; 32, Miike, Miyakonojo City, 26. Jun. 1996; 33, Hayato, Aira, Kagoshima Pref., 26. Jun. 1996; 34, Kirishima, Aira, Kagoshima Pref., 26. Jun. 1996; 35, Kagoshima Univ. Campus, 16. Mar. 1995-25. Oct. 1995; 36, Shiroyama, Kagoshima City, 19. Sep. 1996.

aphid species (Table 3). Among them, 3 species, Aphis gossypii Glover, Aphis spiraecola Pach, and Toxoptera odinae (Van der Goot), were also fed upon by Japanese populations, whilst the remaining 4 were not recorded as hosts of Japanese $A$. aphidimyza (Table 2).

In contrast, some aphid species have never been found to be attacked by $A$. aphidimyza, al- 
Table 2. Aphid species attacked by Japanese populations of Aphidoletes aphidimyza

\begin{tabular}{|c|c|c|}
\hline Aphid species & Host plant & Collection data ${ }^{1}$ \\
\hline \multicolumn{3}{|l|}{ [Aphidinae: Aphidini] } \\
\hline Aphis clerodendri Matsumura & Clerodendrum trichotomum (Verbenaceae) & 36 \\
\hline Aphis craccivora Koch & Phaseolus vulgaris (Fabaceae) & 25 \\
\hline Aphis glycines Matsumura & Glycine max (Fabaceae) & 5 \\
\hline \multirow[t]{13}{*}{ Aphis gossypii Glover } & Abelmoschus esculentus (Malvaceae) & 20 \\
\hline & Cayratia japonica (Vitaceae) & 9 \\
\hline & Chrysanthemum morifolium (Asteraceae) & 27 \\
\hline & Colocasia esculenta (Araceae) & 13 \\
\hline & Commelina communis (Commelinaceae) & 35 \\
\hline & Cucumis melo (Cucurbitaceae) & 30 \\
\hline & Cucumis sativus (Cucurbitaceae) & $2,6,10,13-15,27$ \\
\hline & Fragaria xananassa (Rosaceae) & 21 \\
\hline & Hibiscus mutabilis (Malvaceae) & 22 \\
\hline & Lycopersicon esculentum (Solanaceae) & 17 \\
\hline & Polymnia sonchifolia (Asteraceae) & 1 \\
\hline & Solanum melongena (Solanaceae) & $3,6,11,12,16,25$ \\
\hline & Solanum tuberosum (Solanaceae) & 27 \\
\hline \multirow[t]{3}{*}{ Aphis spiraecola $\mathrm{Pach}$} & Citrus unshiu (Rutaceae) & 19,24 \\
\hline & Pyrus pyrifolia (Rosaceae) & 6 \\
\hline & Viburnum suspensum (Caprifoliaceae) & 35 \\
\hline Hyalopterus pruni (Geoffroy) & Prunus persica (Rosaceae) & 28 \\
\hline Melanaphis formosana (Takahashi) & Sorghum bicolor (Poaceae) & 35 \\
\hline Melanaphis sacchari (Zehntner) & Sorghum bicolor (Poaceae) & 35 \\
\hline Toxoptera odinae (Van der Goot) & Viburnum suspensum (Caprifoliaceae) & 35 \\
\hline \multicolumn{3}{|l|}{ [Aphidinae: Macrosiphini] } \\
\hline \multirow[t]{2}{*}{ Macrosiphum euphorbiae (Thomas) } & Lycopersicon esculentum (Solanaceae) & 7,8 \\
\hline & Solanum melongena (Solanaceae) & 8 \\
\hline Micraphis artemisiae (Takahashi) & Artemisia princeps (Asteraceae) & $25,29,32$ \\
\hline \multirow[t]{4}{*}{ Myzus persicae (Sulzer) } & Brassica oleraceae (Brassicaceae) & 4 \\
\hline & Nicotiana tabacum (Solanaceae) & 30 \\
\hline & Prunus mume (Rosaceae) & 24 \\
\hline & Sesamum indicum (Pedaliaceae) & 7 \\
\hline Myzus siegesbeckiae Takahashi & Prunus $\times$ yedoensis (Rosaceae) & $23,26,28,31$ \\
\hline \multirow[t]{2}{*}{ Myzus varians Davidson } & Prunus mume (Rosaceae) & 33,34 \\
\hline & Prunus persica (Rosaceae) & 28 \\
\hline \multirow[t]{2}{*}{ Neotoxoptera formosana (Takahashi) } & Allium fistulosum (Liliaceae) & 18,24 \\
\hline & Allium tuberosum (Liliaceae) & 27 \\
\hline Phorodon japonensis Takahashi & Humulus japonicus (Moraceae) & 35 \\
\hline Semiaphis heraclei (Takahashi) & Apium leptophyllum (Apiaceae) & 27 \\
\hline \multirow[t]{2}{*}{ Uroleucon sp. } & Solidago altissima (Asteraceae) & 36 \\
\hline & Solidago virgaurea var. asiatica (Asteraceae) & 30 \\
\hline \multicolumn{3}{|l|}{ [Drepanosiphinae] } \\
\hline Myzocallis kuricola (Matsumura) & Castanea crenata (Fagaceae) & 10 \\
\hline
\end{tabular}

${ }^{1}$ See caption of Fig. 1 for collection data indicated by numerals.

though their colonies were encountered frequently during the field surveys. They are listed in Table 4, together with their host plant records and the intensity of field surveys.
Aphid species that were attacked by $A$. aphidimyza were found on 34 plant species (Table 2). Among them those belonging to the families Rosaceae and Asteraceae were most 
Table 3. Japanese aphid species and host plants on which the larvae of imported Aphidoletes aphidimyza were reared to adults

\begin{tabular}{ll}
\hline \multicolumn{1}{c}{ Aphid species } & \multicolumn{1}{c}{ Host plant } \\
\hline Aphidinae: Aphidini & \\
Aphis gossypii Glover & Cucumis sativus (Cucurbitaceae) \\
Aphis spiraecola Pach & Citrus unshiu (Rutaceae) \\
Aphis rumicis L. & Rumex japonicus (Polygonaceae) \\
Toxoptera aurantii & \\
$\quad$ (Boyer de Fonscolombe) & Distylium racemosum (Hamamelidaceae) \\
Toxoptera odinae (Van der Goot) & Viburnum suspensum (Caprifoliaceae) \\
\hline Aphidinae: Macrosiphini & \\
Hyperomyzus lactucae (L.) & Sonchus oleraceus (Asteraceae) \\
Megoura crassicauda Mordvilko & Vicia faba (Fabaceae) \\
\hline
\end{tabular}

Table 4. Aphid species which were not attacked by Aphidoletes aphidimyza in Japan

\begin{tabular}{|c|c|c|}
\hline Aphid species and associated host plant & No. sites surveyed & Colonies examined \\
\hline \multicolumn{3}{|l|}{ Aphidinae: Macrosiphini } \\
\hline \multicolumn{3}{|l|}{ Acyrthosiphon nipponicum (Essig et Kuwana) } \\
\hline on Paederia scandens (Rubiaceae) & 5 & $>30$ \\
\hline \multicolumn{3}{|l|}{ Lachninae } \\
\hline \multicolumn{3}{|l|}{ Lachnus tropicalis (Van der Goot) } \\
\hline on Castanea crenata (Fagaceae) & 4 & $>100$ \\
\hline \multicolumn{3}{|l|}{ Drepanosiphinae } \\
\hline \multicolumn{3}{|l|}{ Neophyllaphis podocarpi Takahashi } \\
\hline on Podocarpus macrophyllus (Podocarpaceae) & 2 & $>30$ \\
\hline \multicolumn{3}{|l|}{ Thelaxinae } \\
\hline \multicolumn{3}{|l|}{ Neothoracaphis yanonis (Matsumura) } \\
\hline on Quercus glauca (Fagaceae) ${ }^{1}$ & 1 & $>50$ \\
\hline \multicolumn{3}{|l|}{ Hormaphidinae } \\
\hline \multicolumn{3}{|l|}{ Pseudoregma bambucicola (Takahashi) } \\
\hline on Bambusa multiplex (Poaceae) & $>60$ & $>200$ \\
\hline
\end{tabular}

${ }^{1}$ Secondary host from May to December. Leaf galls are produced on the primary host, Distylium racemosum (Hamamelidaceae).

abundant, whilst there was only 1 species in the family Poaceae.

\section{Parasitoids and predators}

No hymenopterous parasitoids were reared from the larvae of $A$. aphidimyza but several mature larvae of the genus Lestodiplosis, another group of predacious Cecidomyiidae, were found in the collection from Nishigoshi, Kumamoto Prefecture. In addition, a female midge with mottled wings, which are characteristic of some Lestodiplosis species, was observed ovipositing near a colony of Phorodon japonensis Takahashi on Humulus japonicus Sieb. et
Zucc. (Moraceae) in the Kagoshima University Campus.

\section{Ants attending upon aphid colonies}

During the course of field surveys, 3 species of ant, Paratechia flavipes (F. Smith) (Formicinae), Pristomyrmex pungens Mayr and Tetramorium caespitum (L.) (Myrmicinae), were occasionally observed attending upon aphid colonies. Even when the colonies were attacked by larvae of $A$. aphidimyza, these ants did not show any defensive action to remove the predators from the colonies. 


\section{DISCUSSION}

\section{Identification}

It was in the book 'Illustrated Insect Larvae of Japan' (Ninomiya, 1959) that an aphidophagous species of Cecidomyiidae first appeared in Japanese literature. Ninomiya, one of the co-authors of that book, published an illustration of a larva and tentatively identified it as A. meridionalis, a North American species. Since the name $A$. meridionalis was included in a catalogue (Yasumatsu and Watanabe, 1964), that name has been used on many occasions for any aphidophagous larvae of Cecidomyiidae found in Japan. Although Ninomiya's specimens have been lost and the larval illustration does not give sufficient detail, his specimens may be identical with $A$. aphidimyza, since no other Palearctic or Nearctic species have yet been detected in Japan through the present field surveys (see Harris, 1973 for the distribution and host range of the other species). Furthermore, Ninomiya's identification is considered to be supported by the fact that $A$. meridionalis was later synonymized with $A$. aphidimyza by Gagné (1971).

Since there are no clear diagnostic morphological differences at the subspecies level between Japanese and European specimens, intraspecific variations should be studied at the DNA level before Japanese populations are contaminated by mating with individuals imported from foreign countries.

\section{Distribution and abundance of $A$. aphidimyza}

A. aphidimyza in Japan was first identified by Yukawa (1971), who reared adults from larvae feeding upon Melanaphis sacchari (Zehntner) (=Longiunguis) on Sorghum leaves in Kanoya City, Kagoshima Prefecture. Thereafter, aphidophagous cecidomyiids were recorded from Yamaguchi (Kato, 1974, 1976, as $A$. aphidimyza), Shimane (T. Murai, 1994, personal comm., as $A$. aphidimyza), and Wakayama Prefecture (Morishita et al., 1994, as Aphidoletes sp.). The present study added collection data from 21 prefectures, indicating clearly that $A$. aphidimyza is distributed widely in Japan, except Okinawa Prefecture (Fig. 1). The field surveys also indicated that $A$. aphidimyza is not rare, since the larvae were found at $45(65.2 \%)$ of 69 sites (Table 1). These results were not unexpected in view of its known polyphagy and cosmopolitan distribution as shown in Harris (1973).

$A$. aphidimyza was not found in Okinawa Prefecture during the present study. Generally speaking, a species may be erroneously recorded as absent when collecting has been insufficient or at the wrong season, or when a species is rare. In the case of $A$. aphidimyza, it is not a rare species, as mentioned in the preceding paragraph, and the collection in Okinawa Prefecture was attempted twice in different seasons (first in July and second in November) at a total of 17 sites (Table 1). Therefore, the species may well be absent from Okinawa. However, considering the fact that $A$. aphidimyza occurs in Egypt, Sudan, and Hawaii (Harris, 1973), it is still worth continuing field surveys in Okinawa Prefecture, which is located between latitudes $24^{\circ} \mathrm{N}$ and $26^{\circ} \mathrm{N}$, particularly in the hope of detecting a non-diapausing population of $A$. aphidimyza, which might be useful in short-day seasons.

\section{Aphid species and their host plants}

As has been noted in other countries, $A$. aphidimyza also has a wide host range in Japan consisting of at least 19 aphid species (Table 2). It was remarkable that 16 species were newly added to the known host range in the world. Of course, many more aphid species will be detected as hosts in the future, in particular when aphids inhabiting wild hosts are searched extensively.

In addition, the larvae derived from $A$. aphidimyza imported from the Netherlands to Japan were reared to adults by feeding with 7 Japanese aphid species (Table 3). When all these aphid species are regarded as hosts, the number of host aphid species totals at least 80 in the world.

Plant species of the family Poaceae, such as wheat and barley, have been used successfully as banker plants to aid establishment of aphid natural enemies (Bennison, 1992; Bennison and Corless, 1992) since aphids associated with Poaceae usually do not feed on crops of Dicotyledoneae including Rosaceae, Cucurbitaceae, 
Solanaceae, etc. Therefore, further effort to find host aphids associated with Poaceae is necessary in order to provide suitable banker plants in Japan since only 2 aphid species, Melanaphis sacchari (Zehntner) and Melanaphis formosana (Takahashi), on sorghum are available at the moment (Table 1).

Some aphid species have never been found to be attacked by $A$. aphidimyza (Table 4), even though their colonies were frequently encountered in the field. This is unsurprising since they belong to subfamilies other than Aphidinae, except Acyrthosiphon nipponicum (Essig et Kuwana) which belongs to the tribe Macrosiphini of Aphidinae. The reason why $A$. nipponicum on Paederia scandens (Lour.) Merr. (Rubiaceae) is not attacked by $A$. aphidimyza may be explained by the fact that the aphid contains 'paederoside', an iridoid glycoside originating in the aphid host, $P$. scandens, which is a potent deterrent against predatory ladybird beetles (Nishida and Fukami, 1989).

\section{Parasitoids and predators}

At least 4 species of hymenopterous parasitoids, Synopeas rhanis (Walker) (Platygastridae), Aphanogmus fulmeki Ashmead (Ceraphronidae), Gastrancistrus sp. (Pteromalidae), and a braconid species (not yet identified) are known to attack $A$. aphidimyza (Gilkeson et al., 1993), but fortunately none were reared from the Japanese populations. However, several larvae of the genus Lestodiplosis were found in the collection from Nishigoshi, Kumamoto Prefecture. Larvae of this genus are known to prey on some species of mites, aphids, and certain beetle larvae but they are most commonly found feeding on the larvae of other cecidomyiids (Harris, 1966; Nijveldt, 1969). Therefore, it is probable that the larvae of Lestodiplosis prey on those of $A$. aphidimyza rather than on aphids. If so, though such evidence was not reported previously, the existence of Lestodiplosis larvae must be taken into consideration in the practical use of $A$. aphidimyza in Japan. Further observations are required for confirmation since larvae of Lestodiplosis that were collected could not be reared into adults in the laboratory.

\section{Ant attending upon aphid colonies}

Some ants are generally known to act as defenders against various species of predators attacking aphid colonies (e.g., Dixon, 1985), but the 3 species of ant observed during the present study did not show any defensive action, ignoring the existence of $A$. aphidimyza larvae in aphid colonies. The disturbance of larval activities by ants, if any, cannot be overlooked when $A$. aphidimyza is used as a biological control agent in glasshouses. Further data are needed to study the interactions between aphids, ants, and the predator.

\section{ACKNOWLEDGEMENTS}

We would like to express our cordial thanks to Dr. K. M. Harris (the former Director of the International Institute of Entomology, UK) for his comments and information. Some of the aphids were identified by Dr. M. Sorin (Kôgakkan Univ.) and ants by Mr. K. Tsuda (The Association of Kagoshima Environmental Research and Service), to whom we are deeply indebted. We are also grateful to Tomen Corporation (Tokyo) and Sankei Chemical (Kagoshima) for their support in various ways. Our thanks are also due to the following persons for their kind help in collecting midge larvae in various prefectures: Messrs. J. Abe (Kagoshima Univ.), N. Arakaki (Okinawa AES), K. Furukawa (Hokkaido AES), S. Hamada (Chûgoku NAES), Y. Hashimoto (Hokkaido AES), T. Kato (Saga City, previously in Yamaguchi AES), S. Koyano (Tokyo AES), Y. Kunimoto (Nara AES), T. Kushida (Aomori Apple Tree ES), H. Matsuda (Kagoshima AES), Y. Miura (Kagawa AES), M. Morishita (Wakayama AES), T. Moriya (Kagoshima Univ.), T. Murai (Okayama Univ.), J. Nagamine (Yamagata AES), Y. Nakamura (Nagasaki FES), K. Nakano (Niigata HES), T. Nakata (Hokkaido NAES), P. O. Ngakan (Kagoshima Univ.), T. Niiyama (Akita AES), T. Noda (Hitoyoshi Agric. Ext. Serv.), K. Ohno (Fukuoka AES), T. Okada (Shikoku NAES), K. Shibuya (Kagoshima Univ.), N. Shimada (Tokyo AES), M. Sonehara (Zennôkyô, Tokyo), N. Takahashi (Kyushu Univ.), A. Takai (Tomen Corp., Ibaraki), K. Takesaki (Kagoshima AES), A. Tanaka (Tokunoshima Branch of Kagoshima AES), K. Teramoto (Nagasaki AES), Y. Yamasaki (Ehime AES), and S. Yamauchi (Ryûkyû Sankei, Okinawa).

\section{REFERENCES}

Bennison, J. A. (1992) Biological control of aphids on cucumbers: use of open rearing systems or 'banker plants' to aid establishment of Aphidius matricariae and Aphidoletes aphidimyza. Mededelingen Fac. Landbouw. Univ. Gent. 57 (2b): 457-466.

Bennison, J.A. and S.P. Corless (1992) Biological control of aphids on cucumbers: further development of open rearing units or 'banker plants' to aid establishment of aphid natural 
enemies. Bull. OILB SROP. 16: 5-8.

Dixon, A. F. G. (1985) Aphid Ecology. Blackie, Glasgow, 157 pp.

Gagné, R.J. (1971) The genus Aphidoletes Kieffer (Diptera: Cecidomyiinae) in North America. Ent. News 82: 177-181.

Gilkeson, L.A., J.P. McLean and P. Dessart (1993) Aphanogmus fulmeki Ashmead (Hymenoptera: Ceraphronidae), a parasitoid of Aphidoletes aphidimyza Rondani (Diptera: Cecidomyiidae). Can. Entomol. 125: 161-162.

Grover, P., M. Ved and V. Kashyap (1988) Biology of Aphidoletes aphidimyza Rondani. Cecid. Int . 9: 65-82.

Halima-Kamel, M.B.B. and M.H.B. Hamouda (1993) Les pucerons des cultures protégées et leurs ennemis en Tunisie. Tropicultura 11: 50-53.

Harris, K. M. (1966) Gall midge genera of economic importance (Diptera: Cecidomyiidae) Part 1: Introduction and subfamily Cecidomyiinae; supertribe Cecidomyiidi. Trans. R. Ent. Soc. Lond. 118: 313 -358.

Harris, K.M. (1973) Aphidophagous Cecidomyiidae (Diptera): taxonomy, biology and assessments of field populations. Bull. Ent. Res. 63: 305-325.

Kato, T. (1974) Synchronization of aphidophagous insects with two species of aphids, Aphis spiraecola Patch and Toxoptera citricidus Kirkaldy in citrus groves. Ôdôkon-Chûgoku No. 16: 25-31 (in Japanese).

Kato, T. (1976) Bionomics of Aphidoletes aphidimyza (Rondani) attacking the spirea aphid, Aphis spiraecola Patch in citrus groves. Ôdôkon-Chûgoku No. 18: 1-4 (in Japanese).

Kulp, D., M. Fortmann, M. Hommes and H. P. Plate (1989) Die rauberische Gallmucke Aphidoletes aphidimyza (Rondani) (Diptera: Cecidomyiidae): Ein bedeutender Blattlauspradator, Nachschlagewerk zur Systematik, Verbreitung, Biologie, Zucht und Anwedung. Mitteilungen aus der Biologischen Bundesanstalt fur Land- und Forstwirtschft, Berlin-Dahlem. 126 pp.

Meadow, R. H., W. C. Kelly and A. M. Shelton (1985) Evaluation of Aphidoletes aphidimyza (Dip.: Cecidomyiidae) for control of Myzus persicae (Hom.: Aphididae) in greenhouse and field experiments in the United States. Entomophaga 30: 385-392.
Morishita, M., S. Yano and K. Azuma (1994) Seasonal incidence of tetranychid mites, the cotton aphid, Aphis gossypii Glover and their predators in watermelon fields. Proc. Kansai Pl. Prot. No. 36: 7-11 (in Japanese with English summary).

Morse, J. G. and B. A. Croft (1987) Biological control of Aphis pomi (Hom.: Aphididae) of Aphidoletes aphidimyza (Dip.: Cecidomyiidae); a predator-prey model. Entomophaga 32: 339-356.

Nijveldt, W. (1969) Gall Midges of Economic Importance. Vol. VIII: Gall Midges-Miscellaneous. Crosby Lockwood, London. $221 \mathrm{pp}$.

Nijveldt, W. (1988) Cecidomyiidae. In Aphids Their Biology, Natural Enemies and Control. Vol. 2B (A. K. Minks and P. Harrewijn eds.). Elsevier, Amsterdam, pp. 271-277.

Ninomiya, E. (1959) Aphidoletes meridionalis Felt? In Illustrated Insect Larvae of Japan (T. Esaki, T. Ishii, A. Kawada, T. Shiraki and H. Yuasa eds.). Hokuryûkan, Tokyo, p. 656 (in Japanese).

Nishida, R. and H. Fukami (1989) Host plant iridoid-based chemical defense of an aphid, Acyrthosiphon nipponicum, against ladybird beetles. J. Chem. Ecol. 15: 1837-1846.

Roberti, D. (1946) La Phenobremia aphidimyza (Rond.) (Diptera: Cecidomyidae) predatrice di Aphis (Doralis) frangulae Koch. Boll. Ist. Ent. Univ. Bologna 15: 233-256.

Rondani, C. (1847) Osservazioni sopra parecchie specie di esapodi Afidicidi e sui loro nemeci. Nouvi Ann. Sci. nat. Bologna 8: 337-351, 432-448.

Yasumatsu, K. and C. Watanabe, eds. (1964) A Tentative Catalogue of Insect Natural Enemies of Injurious Insects in Japan. Part 1. Parasite-Predator Host Catalogue. Entomol. Lab., Fac. Agric., Kyushu Univ., Fukuoka. 166 pp. (in Japanese).

Yukawa, J. (1971) A revision of the Japanese gall midges (Diptera: Cecidomyiidae). Mem. Fac. Agric. Kagoshima Univ. 8: 1-203.

Zhao, J. H. and H. K. Cheng (1990) Effect of several sorts of insecticide on Aphidoletes aphidimyza (Dip.: Cecidomyiidae). Chinese J. Biol. Control 6: 185 (in Chinese). 